\title{
THE APPLICATION OF STANDARD OPERATING PROCEDURES IN HOSPITALITY IN THE TERRITORY OF THE CITY OF NOVI SAD
}

\author{
Jovana RoganovićA , Bojana Kalenjuk', Biljana Grubor ${ }^{B}$, \\ Goran RadivojevićA , Miloš ĆirićA \\ Received: August 24, 2019 | Accepted: November 16, 2019 \\ DOI: 10.5937/ZbDght1902174R
}

\begin{abstract}
The medically safe and high-quality food has an overwhelming impact on competitiveness in the hospitality market. Demands for safe and high-quality products have led to defining the SOP (standard operating procedures), that is, a set of directions required for creating a good hygienic and production practice, which also refers to the necessary measurements concerning critical points in production - preparation of dishes. In order to see the quality of operations in the hospitality market, the existence of the $S O P$ is examined, during the food reception, storage and preparation in restaurant kitchens. The aim of the paper is to show to what extent the management and employees in hospitality facilities in Novi Sad are acquainted with the significance of the SOP for successful business operations of a hospitality facility, as well as to examine the extent of its application.
\end{abstract}

Keywords: safe food, standard operating procedures, hospitality, restaurant management.

\section{INTRODUCTION}

The SOP represents a set of directions required for creating good hygienic and production practice, while it also refers to necessary measurements at critical production points (Yibeltal, Simenew, 2014). Standard operating procedures contain detailed procedures for performing tasks in a standardized manner (Nadvi, Waltring, 2004; Lelieveld et al., 2005; Kalenjuk et al., 2011; Popov - Raljić, Blešić, 2016; Cvetković et al, 2016). Food safety does not rest (Rocourt et al., 2003; British Retail Consortium - BRC., 2017), noncompliance with safety standards and quality of products is a real hazard (Popović et

\footnotetext{
A University of Novi Sad, Faculty of Sciences, Department of Geography, Tourism and Hotel Management, Square of Dositej Obradović 3, 21000 Novi Sad, Serbia

B Hospitality and Tourism Stuff School, Jug Bogdanova 28, 1100o Belgrade, Serbia; contact: biki_cvet@yahoo.com
} 
al., 2017) which has resulted in the development of standards (Trienekens, Zuurbier, 2008). They play an important role in the direction and coordination of food production, trade and consumption in the context of globalization (Hatanaka et al., 2005; Tallontire et al., 2011; Amekawa, 2013; Beghin, 2014). The SOP is a very important aspect of gastronomical management and if adequate procedures are not followed (The Official Gazette of the Republic of Serbia, 34/94, 25/96; The Official Gazette of the Republic of Serbia, 41/2009, 17/2019), health and safety of guests can be endangered (Lambensky, Hause, 1999; Kalenjuk et al., 2013).

The subject of this paper is the application of standard work - operating procedures and their importance upon reception, storage and preparation of food in hospitality.

The aim of the paper is to show the extent to which the management and employees in hospitality facilities in Novi Sad are acquainted with the importance of the SOP for successful business operations of a hospitality facility, as well as to examine the extent of its application.

The task of the paper is to apply survey research in order to find the answers for the following questions:

- Are the SOPs upon reception, storage and preparation of food defined?

- Are they, and to what extent, implemented and followed by the management and employees in a hospitality facility?

- Are employees familiar with the importance of the SOP upon reception, storage and preparation of food and their influence on positive business operations of a hospitality facility, as well as safety of the guests?

- Providing there are appropriate procedures, in what way are they followed and who controls their implementation?

\section{LITERATURE REVIEW}

Losing a market because of non-compliance with safety standards and product quality represents a real danger (Popović et al, 2017). One of the preconditions for producing safe and high quality products is compliance with the standard operating procedures. They are an inseparable part of food production and further actions, until its consumption (Bain et al., 2013). They are used as a basis for creating consumer confidentiality (Bain et al., 2013; Dević et al, 2015). Standard operating procedures are required for all HACCP plans, that is, they have a major role in safety of facilities and served food and they are effective only if they are followed (Paster, 2007).

The struggle for high-quality, and at the same time medically safe foodstuffs, starts at the stages of raw materials supply. In addition to certificates and standards which suppliers must possess, it is very important that efficient delivery and reception of foodstuffs exist, delivery times must be respected, hygiene and temperature in a vehicle must be at an appropriate level, and labels must be controlled, and products must be examined at the time of delivery (Kalenjuk i sar, 2011; Tešanović, 2017). It is of extreme importance that there are appropriate procedures which will be applied and which will be familiar to employees in a facility, especially to employees in charge of receiving foodstuffs 
(Škrinjar, Tešanović, 2007). Special attention should be paid to the area for storing food and its ingredients (Popov - Raljić, Blešić, 2016), where three parameters must be measured and controlled, and these are: temperature, humidity and hygiene of storing premises (Hale Feinstein, Stefanello, 2008).

In the process of food preparation there are numerous places which represent critical points at which contamination might occur. Regular cleaning reduces the number of microorganisms to an acceptable level. Rooms for production, storing and selling - serving food and beverages, appliances and equipment for production, preparation, serving and sale must be clean, and cleaning measures, washing and disinfection as general measurements must be conducted daily (FAO, 2005), but first they must be defined in detail and familiar to all employees in the chain.

The Food Safety Law prescribes the obligation to establish a food safety system at all stages of food production, processing and marketing, except at the level of primary production in accordance with the principles of good manufacturing and hygiene practice and hazard analysis and critical control points (HACCP) (EBRD, 2017; The Official Gazette of the Republic of Serbia, 41/2009, 17/2019). Standard operating procedures are a prerequisite for obtaining a medically safe and high-quality product, and for a hospitality facility to operate successfully, it is necessary to define them, to follow them by the management and employees, who must be completely aware of their importance and there must be a person in charge of controlling their implementation.

\section{THE RESEARCH METHODOLOGY}

The research was conducted in the period between $10^{\text {th }}$ August 2019 and $19^{\text {th }}$ September 2019 among employees in different types of hospitality facilities in Novi Sad.

The research was conducted by survey. The obtained data are sorted, statistically processed and graphically presented in the paper. A total of 142 surveys were collected for the purposes of this survey, 78 were completed correctly, and for the purposes of this paper, a portion of relevant data is presented.

\section{THE RESULTS OF THE RESEARCH AND DISCUSSION}

\section{The analysis of socio-demographic data of the respondents}

The respondents in kitchens of hospitality facilities of Novi Sad were predominately male employees with the share of 54\%. Most respondents were between 18 and 30 years of age, which implies that younger population is employed in hospitality industry. Most respondents completed secondary education. Slightly more than $23 \%$ of respondents graduated from higher education institutions, whereas $11 \%$ of respondents graduated from universities and are in senior positions in hospitality facilities. 


\section{The analysis of work of the respondents in hospitality}

A significant number of respondents has worked in hospitality between 2 and 5 years (45\%), 34\% of respondents has worked in hospitality between 6 and 10 years, slightly more than $11 \%$ of respondents has between 11 and 20 years of work experience.

The largest number of respondents currently work as cooks (66\%), 28\% of respondents are chefs and these are mainly respondents with more years of work experience in hospitality.

The last survey question in this group examines work experience at the current position in a hospitality facility, where based on the results, we can conclude that the largest number, as many as $54 \%$ of respondents have between 1 and 5 years of work experience.

\section{Analysis of characteristics of a hospitality facility}

The largest number of respondents are employed in 'a la cart' restaurants. The second place belongs to the employed in boarding hotels, and the smallest number are employees in specialized restaurants.

The largest percentage of the surveyed hospitality workers are employed in a facility which daily produces between 51 and 100 meals (43\%), 36\% are hospitality facilities which produce between 101 and 200 meals, whereas $11 \%$ of respondents say that their hospitality facility produces up to 50 meals on a daily basis.

\section{Analysis of implementation of standard operating procedures in hospitality}

Examining the knowledge and implementation of the SOP in hospitality facilities yielded crucial data in successful medically safe and operational business, which is shown in Table 1 . The research has shown that as many as $91 \%$ of respondents answered that they are familiar with the importance of standard operating procedures, which supports this research.

When asked if suppliers respect the contracted delivery times, it was found that suppliers mostly respect the contracted times with a significant share of $91 \%$, while $6 \%$ of the respondents stated that suppliers do not respect the contracted times, and the remaining 3\% stated that suppliers do not respect the contracted time because the time is not contracted.

Based on the answers of respondents in hospitality facilities in Novi Sad, we can conclude that $60 \%$ have persons trained for and in charge of receiving goods.

The hygiene of transporting vehicles is very important and must by no means be neglected. Based on the results, it is concluded that as many as $46 \%$ of respondents employed in the kitchen sector of hospitality facilities in Novi Sad state that the hygiene of transporting vehicles is controlled, while $34 \%$ of respondents claimed negative, and the remaining $20 \%$ stated that is controlled only sometimes. 
Table 1. Implementation of SOP in hospitality facilities $-1^{\text {st }}$ part $(n=78)$

\begin{tabular}{|l|l|c|c|}
\hline QUESTIONS & CLAIMS & & SHARE \\
\hline \multirow{2}{*}{$\begin{array}{l}\text { There are contracted days in a week or times of a } \\
\text { day when the foodstuffs are delivered by suppliers. }\end{array}$} & Yes & 73 & $93 \%$ \\
\cline { 2 - 4 } & No & 5 & $7 \%$ \\
\hline \multirow{2}{*}{ Suppliers respect the contracted times. } & Yes, they respect them. & 72 & $91 \%$ \\
\cline { 2 - 4 } & No, they do not respect them. & 2 & $3 \%$ \\
\cline { 2 - 4 } & The times are not contracted. & 4 & $6 \%$ \\
\hline \multirow{2}{*}{$\begin{array}{l}\text { There is a trained person in charge of receiving } \\
\text { foodstuffs. }\end{array}$} & Yes. & 47 & $60 \%$ \\
\cline { 2 - 4 } & No. & 31 & $40 \%$ \\
\hline \multirow{2}{*}{$\begin{array}{l}\text { The hygiene of transporting vehicles is } \\
\text { controlled. }\end{array}$} & Yes. & 36 & $46 \%$ \\
\cline { 2 - 4 } & No. & 15 & $34 \%$ \\
\cline { 2 - 4 } & Sometimes. & $20 \%$ \\
\hline
\end{tabular}

The examination of products at the time of delivery is the next important stage. The data about whether during the reception, and before entering the facility foodstuffs are controlled by hospitality workers is shown in Graph 1 .

Unlike the previous question where $54 \%$ of respondents stated that they do not or that they sometimes control the hygiene of the transporting vehicle, control the foodstuffs upon reception is controlled by as many as $88 \%$ of hospitality workers.

The structure of responses to further crucial questions concerning the set research is given in Table 2.

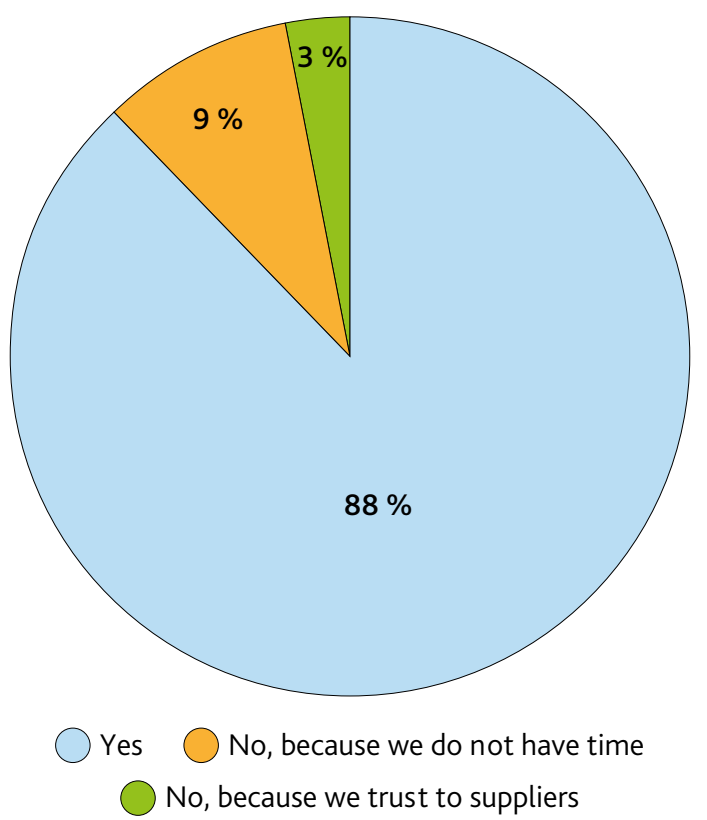

Graph 1. Control of foodstuffs upon reception 
The FIFO rule (first in - first out) refers to monitoring the shelf-life of foodstuffs, thus in this manner the foodstuffs which first arrived in a facility are first used, and those that arrived later are used later, $77 \%$ of respondents abide by this rule, so we may conclude that the majority of respondents is familiar with the above mentioned rule and that hospitality facilities take care of order in warehouses, what foods will be used first, how they will be stacked, etc.

Based on the research on temperature recording in warehouses, we may notice that the majority of respondents who work in hospitality facilities in Novi Sad never record temperature in warehouses, as many as $57 \%$ of respondents, which leads to a conclusion that in such hospitality facilities the required SOP are not fully implemented, among other things, in parts concerning daily recordings of temperature.

Table 2: Implementation of the SOP in hospitality facilities $-2^{\text {nd }}$ part $(n=78)$

\begin{tabular}{|l|l|l|l|}
\hline QUESTIONS & CLAIMS & & SHARE \\
\hline \multirow{4}{*}{ Application of the FIFO rule } & No, never & 0 & $0 \%$ \\
\cline { 2 - 4 } & Almost never & 2 & $3 \%$ \\
\cline { 2 - 4 } & Sometimes & 16 & $20 \%$ \\
\cline { 2 - 4 } & Mostly yes & 26 & $34 \%$ \\
\cline { 2 - 4 } & Yes & 34 & $43 \%$ \\
\hline \multirow{5}{*}{ Temperature is recorded in warehouses } & No, never & 45 & $57 \%$ \\
\cline { 2 - 4 } & Almost never & 2 & $3 \%$ \\
\cline { 2 - 4 } & Sometimes & 4 & $6 \%$ \\
\cline { 2 - 4 } & Mostly yes & 25 & $31 \%$ \\
\cline { 2 - 4 } & Yes & 2 & $3 \%$ \\
\hline \multirow{3}{*}{ There is a person responsible for hygiene in warehouses } & Yes & 53 & $68 \%$ \\
\cline { 2 - 4 } & No & 25 & $32 \%$ \\
\hline Periodic plans for cleaning and disinfection & Yes, for all premises & 61 & $77 \%$ \\
\cline { 2 - 4 } & Only for some rooms & 13 & $17 \%$ \\
\cline { 2 - 4 } & No & 4 & $6 \%$ \\
\hline \multirow{3}{*}{$\begin{array}{l}\text { There are wardrobes, two-part closets for separating civilian } \\
\text { and working shoes and clothes in the hospitality facility }\end{array}$} & Yes & 49 & $63 \%$ \\
\cline { 2 - 4 } & No & 29 & $37 \%$ \\
\cline { 2 - 4 } & No & 55 & $71 \%$ \\
\hline
\end{tabular}

Having analyzed the answers to the question whether there is a person responsible for hygiene in warehouses, we may conclude that $68 \%$ of the respondents, i.e. facilities have a person in charge of hygiene of these premises.

The previous question is linked to the next one, where one wants to obtain data on whether there are periodic cleaning and disinfection plans in hospitality facilities because if there is not a periodic plan for cleaning and disinfection of the premises where products are stored, the medical safety of food is questioned. 
If we look at the results of the research shown in the previous table (Table 1), we notice that the majority of the respondents stated that there is a person in charge of hygiene. Based on this, we conclude that if there is a person in charge of hygiene control, there must also be periodic plans of cleaning and disinfection of all premises (as many as 77\%) whose implementation is control by the above mentioned person in order to avoid inadequate work operations.

The next question in the questionnaire refers to food and beverages consumption in rooms for reception, storing and preparation of food. According to the HACCP standards, food consumption is not allowed in these rooms, that is in the whole kitchen block (Bunčić, 2009). The $63 \%$ of respondents stated that they consume food and beverages in production areas. In hospitality facilities there should be premises for employees' rest and food consumption, because the possibility of food being contaminated would thus be reduced.

Based on the results of answers on the subject of facilities for changing clothes and hygiene of the employees, we conclude that in as many as $71 \%$ of hospitality facilities there are two-part wardrobe closets for separating civilian and work shoes and clothes in hospitality facilities.

Two important factors for controlling the growth of pathogenic microorganisms are time and temperature. The structure of answers to the question whether hospitality workers in restaurants in Novi Sad control the medium temperature during food preparation is shown in Graph 2. Based on the received data, we may conclude that only 37\% of hospitality workers always control the medium temperature during food preparation, whereas $9 \%$ almost always do.

Following the previous question, their knowledge regarding temperature zones was tested, and the response structure is shown in Graph 3, where it can be observed that the majority of respondents $(80 \%)$ know what the critical temperature zone is.

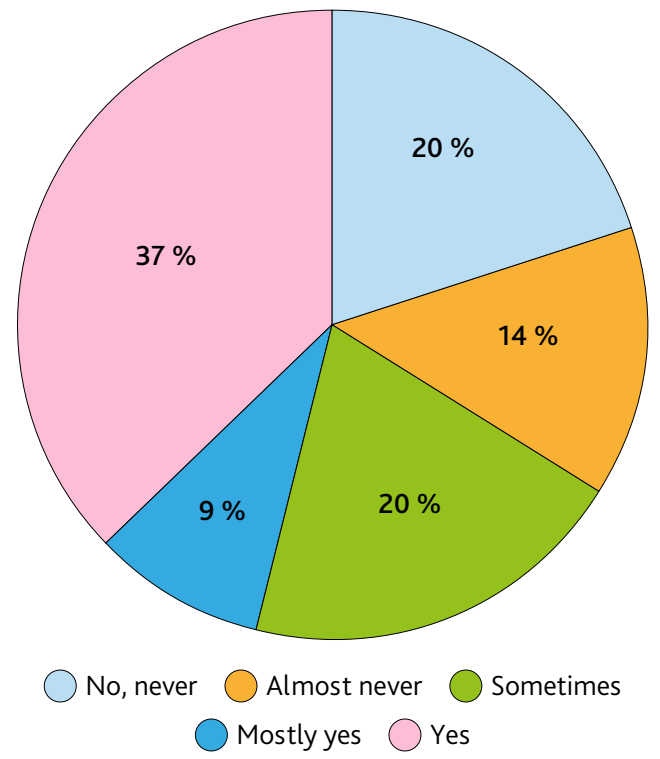

Graph 2. Control of the medium temperature during food preparation 


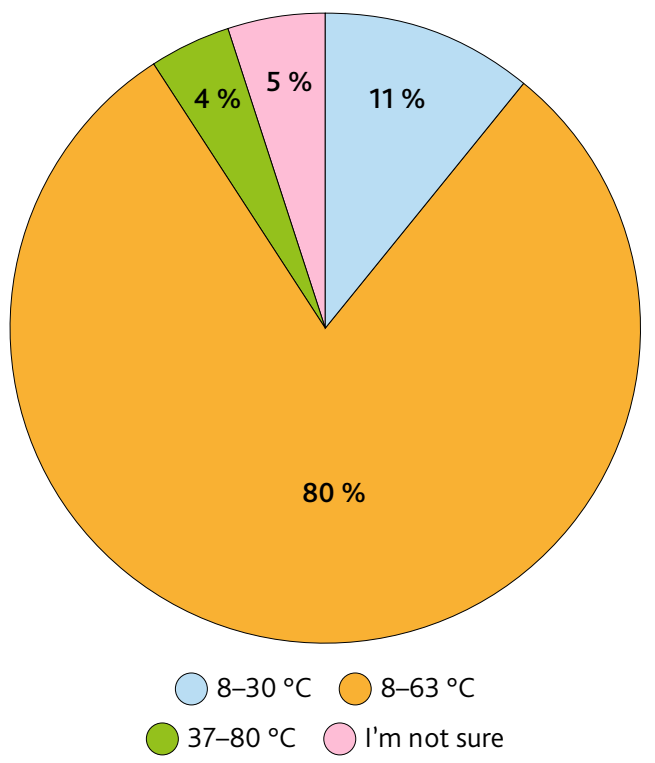

Graph 3. Dangerous temperature zone which should be avoided when keeping food

Modeled on the previous question, a question was asked about the temperatures ideal for the growth of microorganisms (Graph 4), a representative number of $66 \%$ of respondents answered correctly.

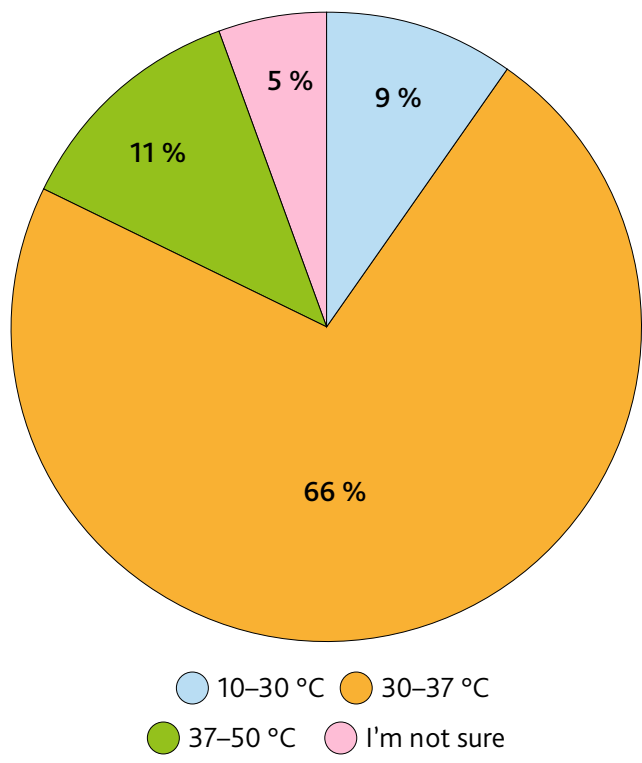

Graph 4. Temperatures at which the growth of microorganisms is most effective 


\section{CONCLUSION}

Based on the research conducted among hospitality workers employed in the territory of the city of Novi Sad, along with the previously consulted relevant literature in the field of gastronomy and hospitality, we reached the conclusion that hospitality workers in the production sector (in the kitchen) are acquainted with the standard operating procedures. However, a problem arises in the very implementation, because unfortunately, they are not adequately implemented regardless of possessing the required paperwork and defined aspects of business operation. This situation on the market significantly reflects the quality of work and calls into question the medical safety of food.

The quality which is not constant, along with safety and regularity of food which are not adequate for business operations of hospitality facilities, call into question business efficiency and, of course, profitability. Therefore, for successful business operations of each hospitality facility, in addition to the defined SOP, it is necessary to strive for them to be fully applicable, which is the main task of all employees in the production and service chain within each hospitality facility.

\section{ACKNOWLEDGEMENT}

This paper represents a part of the research on projects 142-451-2535/2019.

\section{LITERATURE}

Amekawa,Y. (2013). Reconciling Safety and Fairness in Global Agri-Food Standardization. Sociology Mind, 3, 32-38.

Bain, C., Ransom, E., Higgins, V. (2013). Private Agri-food Standards: Contestation, Hybridity and the Politics of Standards. International Journal of Sociology of Agriculture and Food, 20, 1, 1-10.

Beghin, J. C. (2014). The Protectionism of Food Safety Standards in International Agricultural Trade. Agricultural Policy Review, 2014(1), Art. 5, (available at: http://lib. dr.iastate.edu/agpolicyreview/vol2014/iss1/5).

British Retail Consortium - BRC (2017). Global Standard. Food Safety. Quick Guide for Issue 7, (available at: https://www.brcglobalstandards.com/media/27116/brc-food7quick-guide-uk-screen.pdf).

Bunčić, S. (2009). Vodič za razvoj i primenu preduslovnih programa i principa HACCP u proizvodnji hrane, Beograd.

Cvetković, B., Kalenjuk, B., Tešanović, D., Babić, M. (2016). Gastronomic needs of modern tourists as a problem of tourism market, Zbornik radova Departmana za geografiju, turizam i hotelijerstvo, 45-2, 117-131.

Dević, J., Vuksanović, N., Portić, M., Tešanović, D., Kalenjuk, B. (2015). Health aspects of safety in hospitality - inplementation of HACCP system, Eco-conference, $23^{\text {th }}$ and $25^{\text {th }}$ Sptembar 2015., Ecological movement of Novi Sad, pp. 275-282. 
European Bank for Reconstruction and Development - EBRD (2017). New quality label to raise profile of Serbian meats, (available at: http://www.ebrd. com/news/2017/newquality-label-to-raise-profile-of-serbian-meats.html).

FAO (2005). Guidelines on HACCP, GMP and GHP for ASEAN Food SMEs Ed1. ECASE- AN Economic Cooperation Programme on Standards, Quility \& Conformity Assessment (Asia/2003/069-236).

Hale Feinstein, A., Stefanello, J. (2008). Purchasing: selection and procurement for hospitality industry, John Wiley \& Sons, Inc., Hoboken, New Jersey.

Hatanaka, M., Bain, C. Busch, L. (2005). Third-party certification in the global agrifood system, Food Policy, 30, 354-369.

Kalenjuk, B., Branković, V., Cvetković, B. (2013). Healthy safe food manipulation and its significance in the development of tourism in Belgrade. HOTELLINK 21-22, Fifth International Biennial Congress, $28^{\text {th }}$ and $29^{\text {th }}$ November, 2013, 416-423.

Kalenjuk, B., Škrinjar, M., Psodorov, Đ., Korbafinski, M., Gagić, S. (2011). Elementary Skills and Habits on Food Safety of Students in Hospitality and Tourism. Contemporary Trends in Tourism and Hospitality, 2011, Via Danube, the Main Street of Europe, University of Novi Sad, $29^{\text {th }}$ and $30^{\text {th }}$. September, 419-429.

Kalenjuk, B., Tešanović, D., Škrinjar, M., Psodorov, Đ. (2011). Značaj bezbednosti hrane u razvoju turizma. Turističko poslovanje, 7, 155-162.

Lambensky, R.S., Hause, M.A. (1999). On Cooking A Text book Culinary Fundamentals, Prentice Hall, New Jersey, USA.

Lelieveld, H.L.M., Mostert, M.A. Holah, J. (2005). Handbook of hygiene control in the food industry, Woodhead Publishing Limited, Cambridge CB1, England.

Nadvi, K. Waltring, F. (2004). Making sense of global standards, in: H. Schmitz (ed.) Local Enterprises in the Global Economy: Issues of Governance and Upgrading. Cheltenham: Edward Elgar, 53-91.

Paster T. (2007). The HACCP Food Safety Training Manual. John Wiley \& Sons, Inc., Hoboken, New Jersy, United States of America.

Popov - Raljić, J., Blešić, I. (2016). Bezbednost hrane - primena HACCP sistema u ugostiteljstvu i hotelijerstvu, PMF, Novi Sad.

Popović, V., Vuković, P., Ćosić, M. (2017). Food safety and quality policy in the Republic of Serbia. Economics of Agriculture (64) 4, 1607-1617.

Rocourt, J., Moy, G., Vierk, K., Schlundt, J. (2003). The Present State of Foodborne Disease in OECD Countries. Food Safety Department, WHO, Geneva.

Škrinjar, M., Tešanović, D. (2007). Hrana u ugostiteljstvu i njeno čuvanje, Univerzitet u Novom Sadu, Prirodno-matematički fakultet, Departman za geografiju, turizam i hotelijerstvo, Novi Sad.

Tallontire, A., Opondo, M., Nelson, V. Martin, A. (2011). Beyond the vertical? Using value chains and governance as a framework to analyse private standards initiatives in agri-food chains, Agriculture and Human Values, 28, pp. 427-441.

Tešanović, D. (2017). Sanitarna zaštita i bezbednost u hotelijerstvu, Visoka hotelijerska škola, Beograd. 
The Official Gazette of the Republic of Serbia, 34/94, 25/96 (Ordinance on sanitary and hygienic conditions for facilities where the production and marketing of foodstuffs and articles of general use are carried out).

The Official Gazette of the Republic of Serbia, 41/2009, 17/2019 (Food Safety Law).

Trienekens, J. Zuurbier, P. (2008). Quality and safety standards in the food industry, developments and challenges. Int. J. Production Economics 113 (1), 107-122.,

Yibeltal M. M. Simenew K. M. (2014). Significance of HACCP and SSOP in Food Processing Establishments. World Journal of Dairy \& Food Sciences 9 (2): 121-126. 